\title{
Pengaruh Pemberian Bayam Pada Pakan Terhadap Durasi Moulting Kepiting Bakau (Scylla olivacea) di Tambak Kepiting Bakau
}

\section{The effect of spinach on feed on the moulting duration of mangrove crab (Scylla olivacea) in mangrove crab spond}

\author{
Christina Natalia Sihombing*1, Dede Hartono ${ }^{2}$ dan Maya Angraini FU ${ }^{3}$ \\ ${ }^{1,2,3}$ Program Studi Ilmu Kelautan Fakultas Pertanian Universitas Bengkulu, Bengkulu, Indonesia \\ Korespondensi: christinasihombing201@gmail.com
}

\begin{abstract}
ABSTRAK
Kepiting bakau (Scylla olivacea) adalah satu komoditas perikanan yang memiliki nilai ekonomis yang tinggi. Untuk memenuhi permintaan pasar yang cukup tinggi maka perlu dilakukan peningkatan produksi kepiting bakau baik jumlah maupun kualitasnya. Salah satu perkembangan teknologi budidaya perikanan dalam meningkatkan produksi kepiting bakau yakni produksi kepiting lunak atau kepiting soka (soft shell). Tingginya peminat terhadap kepiting soka akan mendorong para pembudidaya untuk memproduksi lebih banyak kepiting soka. Namun ada kendala yang di alami dalam kegiatan produksi kepiting soka yaitu penggunaan metode mutilasi organ tubuh seperti kaki jalan atau kaki renang, hal seperti ini dianggap tidak layak untuk dilakukan dan melanggar hukum. Berdasarkan uji yang telah dilakukan terbukti bahwa ekstrak bayam dapat diberikan melalui pakan buatan dan efektif mempercepat moulting. Tujuan dari penelitian ini adalah untuk menghitung durasi moulting kepiting bakau di tambak kepiting yang diberi tambahan bayam dengan konsentrasi yang berbeda. Penelitian ini menggunakan metode ekperimental, rancangan percobaan yang digunakan dalam penelitian ini adalah Rancangan Acak Lengkap (RAL) dengan 4 perlakuan dan setiap perlakuan memiliki 3 ulangan, pengamatan dilakukan setiap 24 jam. Hasil penelitian diperoleh bahwa terdapat pengaruh konsentrasi bayam terhadap durasi moulting kepiting bakau. Dengan uji Beda Nyata Terkecil maka diketahui bahwa penambahan bayam 60 gr (P4) merupakan konsentrasi yang paling baik, yaitu dengan rata-rata moulting 13 hari dan menjadi durasi yang paling cepat dibandingkan dengan perlakuan lainnya. Hasil pengukuran parameter kualitas air didapatkan suhu berkisar $28-31^{\circ} \mathrm{C}$, salinitas berkisar antara $22-25 \mathrm{ppt}$, derajat keasaman $(\mathrm{pH})$ berkisar 6,9-7,3 dan oksigen terlarut berkisar antara 5,4-6,3 mg/l. Kondisi ini menunjukkan bahwa kualitas perairan cukup baik dan mendukung kehidupan kepiting bakau.
\end{abstract}

Kata Kunci : kepiting bakau, pakan, bayam, durasi moulting

\begin{abstract}
Mangrove crab (Scylla olivacea) are one of the fisheries commodities that have high economic value. To meet high market demand, it is necessary to increase mangrove crab production in both quantity and quality. One of the development in aquaculture technology in increasing the production of mangrove crab is soft shell production. The high interest in soft shell will encourage farmers to produce more soft crab. But there are obstacles experienced in the production of soft shell, namely the use of methods of mutilation of body organs such as walking foot or swimming foot, this is deemed inappropriate and illegal. Based on the test that have been done it is proven that spinach extract can be given through artificial feed and effectively accelerates moulting. The purpose of this research was to calculate the duration of mangrove crab moulting in crab ponds that were added additional spinach with different concentrations. The research used an experimental method, the experimental design used in this study was a Completely Randomized Design (RAL) with 4 treatments and each treatment had 3 replicaations,
\end{abstract}


observations were made every 24 hours. The results were obtained that there was an influence of spinach concentration on the duration of mangrove crab moulting. With the smallest significant difference test it is known that the addition of 60 grams of spinach is the best concentration, which is with an average moulting of 13 days and become the fastest duration compared to other treatments. The measurement result of water quality parameter obtained temperature range $28-31^{\circ} \mathrm{C}$, salinity ranges between $22-25 \mathrm{ppt}$, the degree of acidity $(\mathrm{pH})$ range between 6,9-7,3 and Dissolved oxygen ranges between 5,4-6,3 $\mathrm{mg} / \mathrm{l}$. This condition shows that the water quality is quite good and supports the life of mangrove crabs.

Keywords : mangrove crab, feed, spinach, moulting duration

\section{PENDAHULUAN}

Kepiting bakau (Scylla sp) adalah satu komoditas perikanan yang memiliki nilai ekonomis yang tinggi dan banyak dijumpai di perairan Indonesia terutama di perairan payau di sepanjang pantai yang tempatnya ditumbuhi tanaman mangrove atau sering disebut tanaman bakau. Kepiting bakau di Indonesia diperoleh dari penangkapan stok alam di pesisir khususnya di area estuaria dan hasil budidaya di tambak air payau. Tidak hanya di dalam negeri, kepiting bakau ini juga dikenal baik di pasaran luar negeri karena kepiting bakau memiliki daging yang sangat lezat dan bernilai gizi yang tinggi (Karim, 2013).

Untuk memenuhi permintaan pasar yang cukup tinggi maka perlu dilakukan peningkatan produksi kepiting bakau baik itu jumlah maupun kualitasnya. Salah satu perkembangan teknologi dalam budidaya perikanan dalam meningkatkan produksi kepiting bakau yakni produksi kepiting lunak atau kepiting soka (soft shell). Menurut Fujaya (2007) harga jual kepiting soka lebih tinggi daripada kepiting bercangkang keras yaitu dapat mencapai dua kali lipat.

Produksi kepiting lunak dilakukan dengan memelihara kepiting secara individu dalam kotak (crabs box) yang ditempatkan di dalam tambak hingga moulting. Moulting adalah proses pergantian kulit secara alami, yaitu melepaskan kulit lama yang keras dengan tujuan untuk pertumbuhan. Setelah moulting, kulit kepiting yang baru masih dalam kondisi sangat lunak dan akan mengeras kembali beberapa jam kemudian setelah terjadi penyerapan air. Kepiting dengan kondisi lunak inilah yang dipanen sebagai kepiting soka atau kepiting lunak. Kepiting bakau yang sudah mengalami moulting akan bertambah besar sekitar 1/3 kali dari sebelumnya, selain itu untuk kepiting dewasa, panjang karapas juga meningkat 5-10 mm atau sekitar 2 kali dari ukuran semula (Kordi, 1997 dalam Soviana, 2004). 
Moulting atau disebut sebagai proses ganti kulit atau karapas adalah proses alami yang umum terjadi pada hewan crustacea. Hal ini terjadi karena crustacea sebagai hewan dengan kerangka luar yang keras atau karapas serta tidak dapat tumbuh, sehingga crustacea perlu mengganti karapas atau kerangka luar seiring pertumbuhan tubuhnya. Setiap terjadi moulting maka kepiting akan mengalami penambahan berat atau bobot, pertambahan panjang dan lebar karapas. Pada crustacea sendiri, pertumbuhan merupakan proses perubahan tubuh dan bobotnya yang mampu terjadi secara berkala pada setiap pergantian karapas atau molting (Fujaya et al., 2008).

Tingginya peminat terhadap kepiting soka akan mendorong para pembudidaya untuk memproduksi lebih banyak kepiting soka. Namun ada kendala yang di alami dalam kegiatan produksi kepiting soka yaitu penggunaan metode mutilasi organ tubuh seperti kaki jalan atau kaki renang, hal seperti ini dianggap tidak layak untuk dilakukan dan melanggar hukum. Namun demikian ada metode lain yang ditemukan untuk mempercepat molting yaitu seperti manipulasi lingkungan, penambahan hormon dan pemberian ekstrak tumbuhan atau dapat dilakukan dengan pencampuran bayam secara langsung ke pakan kepiting (Harianto, 2015).

\section{METODE PENELITIAN}

\section{Waktu dan Tempat}

Penelitian ini dilaksanakan pada bulan Maret-April 2020, yang berlokasi di tambak kepiting, Kelurahan Sumber Jaya Kecamatan Kampung Melayu Kota Bengkulu. Peta penelitian dapat dilihat pada Gambar 2. 


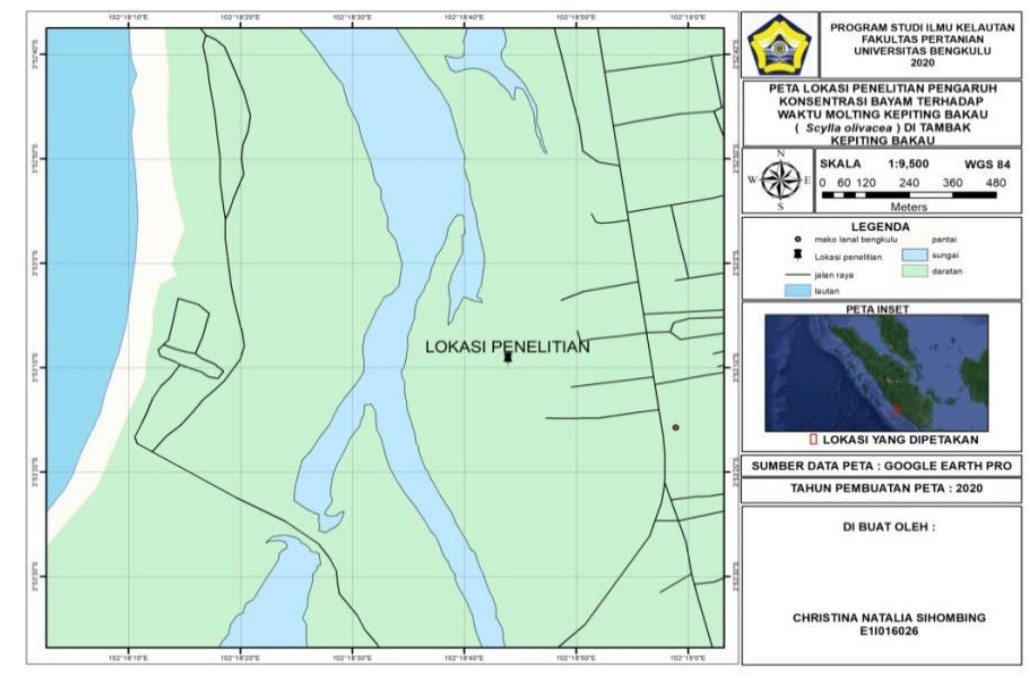

Gambar 2. Peta Lokasi Penelitian

\section{Alat dan Bahan Penelitian}

Penelitian ini menggunakan alat dan bahan sebagai berikut : kamera, alat tulis, keranjang, rakit, timbangan, refraktometer, thermometer, $\mathrm{pH}$ meter, blender, kepiting bakau, bayam, binder, dan ikan rucah.

\section{Prosedur Penelitian}

\section{Kepiting Uji}

Hewan uji yang digunakan adalah kepiting bakau spesies Scylla olivacea yang diperoleh dari hasil tangkapan di tambak kepiting dengan berat berkisar antara 120-150 gram/individu. Jumlah kepiting yang di uji adalah 12 ekor. Kepiting yang dijadikan hewan uji hanya kepiting bakau yang memiliki kondisi sehat yaitu dengan ciri-ciri anggota tubuh lengkap dan memiliki respon aktif terhadap gangguan luar. Selanjutnya kepiting uji diaklimatisasi selama 5 hari pada wadah pemeliharaan (Permadi, 2016).

\section{Wadah Penelitian}

Wadah yang digunakan dalam penelitian ini adalah wadah plastik berbentuk bulat lonjong yang dilengkapi dengan rangka bambu berpelampung untuk meletakkan wadah tempat kepiting tersebut. Setiap wadah plastik diisi dengan 1 individu kepiting bakau yang akan di uji. Hal ini untuk menghindari kanibalisme selama pemeliharaan terutama apabila setelah moulting. 
Kemudian wadah tersebut diapungkan di dalam kolam dengan kedalaman lebih kurang 1 meter. Wadah kepiting dapat dilihat pada gambar 3.

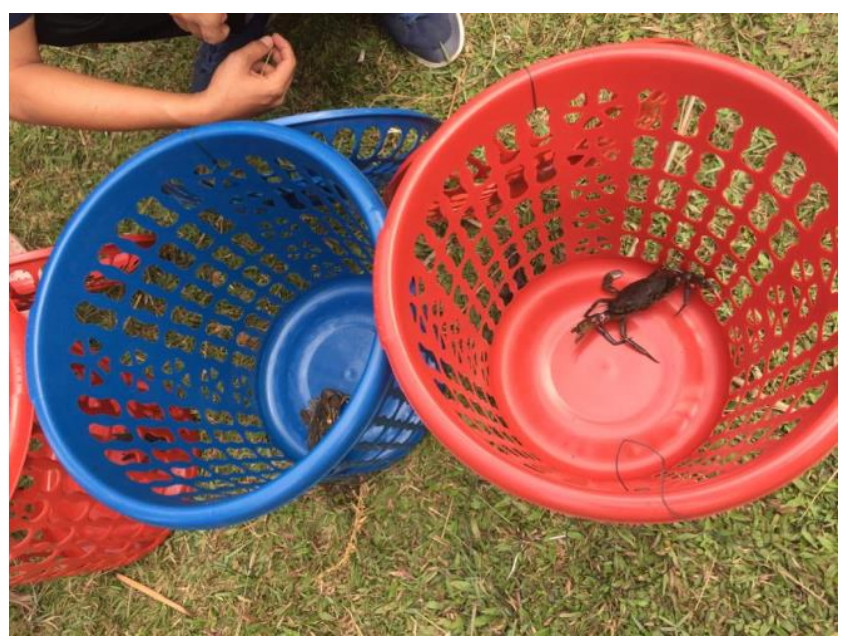

Gambar 3. Wadah Kepiting Uji

\section{Pakan Uji}

Pakan yang digunakan dalam penelitian ini adalah bayam raja (Amaranthus hybridus) dan ikan rucah. Konsentrasi bayam yang digunakan dalam penelitian ini didapat dengan menghaluskan bayam raja. Bagian tanaman yang dipakai yaitu daunnya (Dwi, 2013). Bayam dicampur dengan ikan rucah akan diberikan pada kepiting sebanyak 10\% dari bobot tubuh (Permadi, 2016). Setelah dicampur dan dihaluskan menggunakan blender. Pakan dibentuk bulat menyerupai bakso sebelum diberikan ke kepiting.

\section{Perlakuan}

Penelitian ini merupakan penelitian eksperimental, dilakukan di tambak kepiting bakau di Kelurahan Sumber Jaya, Kecamatan Kampung Melayu Kota Bengkulu. Penelitian ini menggunakan desain Rancangan Acak Lengkap (RAL) dengan 4 perlakuan dan 3 ulangan. Pengamatan kepiting dilakukan setiap 24 jam. Perlakuan pada percobaan ini adalah penambahan konsentrasi bayam yaitu :

$$
\begin{aligned}
& \mathrm{P} 0=\text { Pakan ikan rucah } \\
& \mathrm{P} 1=\text { Pakan dengan konsentrasi bayam } 20 \mathrm{~g} \\
& \mathrm{P} 2=\text { Pakan dengan konsentrasi bayam } 40 \mathrm{~g}
\end{aligned}
$$




$$
\mathrm{P} 3=\text { Pakan dengan konsentrasi bayam } 60 \mathrm{~g}
$$

\section{Parameter Uji}

Adapun parameter yang akan diamati adalah durasi moulting kepiting bakau. Durasi moulting diamati secara langsung setiap 24 jam.

- Bagan pengacakan durasi moulting yang diamati adalah :

\begin{tabular}{|c|c|c|c|}
\hline P1U3 & $20 \mathrm{gr}$ & $0 \mathrm{gr}$ & P0U3 \\
\hline P0U2 & $0 \mathrm{gr}$ & $60 \mathrm{gr}$ & P3U3 \\
\hline P2U3 & $40 \mathrm{gr}$ & $60 \mathrm{gr}$ & P3U2 \\
\hline P2U2 & $40 \mathrm{gr}$ & $20 \mathrm{gr}$ & P1U2 \\
\hline P3U1 & $60 \mathrm{gr}$ & $40 \mathrm{gr}$ & P2U1 \\
\hline P1U1 & $20 \mathrm{gr}$ & $0 \mathrm{gr}$ & P0U1 \\
\hline
\end{tabular}

Keterangan : $\mathrm{P}=$ Perlakuan

$$
\mathrm{U}=\text { Ulangan }
$$

- Pengukuran parameter kualitas air dilakukan secara langsung di tambak kepiting bakau tersebut meliputi salinitas yang diukur dengan menggunakan refraktometer, suhu diukur dengan menggunakan thermometer, $\mathrm{pH}$ diukur dengan menggunakan $\mathrm{pH}$ meter dan oksigen terlarut dengan menggunakan DO meter. Pengukuran kualitas perairan ini dilakukan setiap 1 minggu sekali selama masa penelitian.

\section{Analisis Statistik}

Uji analisis yang digunakan pada penelitian ini yaitu uji analisis dengan analisa statistik menggunakan Analysis of Variance (ANOVA) yang berfungsi untuk mengetahui apakah terdapat perbedaan perlakuan dengan uji $\mathrm{F}$ pada selang kepercayaan 95\%, untuk mengetahui apakah pengaruh perlakuan terhadap parameter yang diamati berpengaruh nyata atau tidak. Jika ada perbedaan nyata $(\mathrm{P}<0,05)$, maka akan diuji lanjut dengan menggunakan Beda Nyata Terkecil (BNT) serta data akan disajikan dalam bentuk tabel dan grafik yang akan dibahas secara deskriptif.

Dasar penentuan keputusan :

1. Jika $\mathrm{F}_{\text {hitung }}>\mathrm{F}_{\text {tabel }}=$ Tolak $\mathrm{H}_{0}$ dan terima $\mathrm{H}_{1}$ 
2. Jika $\mathrm{F}_{\text {hitung }}<\mathrm{Ft}_{\mathrm{abel}}=$ Terima $\mathrm{H}_{0}$ dan tolak $\mathrm{H}_{1}$

Hipotesis mengacu pada kerangka pemikiran dan identifikasi masalah, maka hipotesis yang digunakan pada penelitian ini adalah:

- Durasi moulting kepiting bakau

$\mathrm{H}_{0}=$ Tidak ada pengaruh konsentrasi bayam terhadap durasi moulting kepiting bakau

$\mathrm{H}_{1}=$ Ada pengaruh konsentrasi bayam terhadap durasi moulting kepiting bakau

Jika $F_{\text {hit }}>F_{\text {tabel }}$ maka hipotesis nol ditolak dan berlaku sebaliknya.

\section{HASIL DAN PEMBAHASAN}

\section{Deskripsi Lokasi Penelitian}

Penelitian dilaksanakan di Kelurahan Sumber Jaya yang berada di Kecamatan Kampung Melayu Kota Bengkulu. Secara administratif Kelurahan Sumber Jaya berada di pesisir barat Kota Bengkulu, dimana sebelah Barat berbatasan dengan Kelurahan Kandang. sebelah Selatan berbatasan dengan Kelurahan Teluk Sepang, sebelah Timur berbatasan dengan Kelurahan Betungan dan sebelah Utara berbatasan dengan Kelurahan Kandang Mas.

Di Kelurahan Sumber Jaya terdapat beberapa jenis ekosistem mangrove diantaranya yaitu jenis Avicennia marina, Rhizopora apiculata dan Sonneratia alba yang tumbuh dipinggiran sungai dan sekitar pinggiran tambak. Ekosistem mangrove berasosiasi dengan berbagai macam biota yang salah satunya yaitu kepiting bakau. terdapat 2 jenis kepiting bakau yang dibudidayakan di tambak lokasi penelitian, yaitu kepiting bakau merah (Scylla olivacea) dan kepiting bakau hijau (Scylla serrata). Kepiting bakau yang memiliki nilai ekonomis yang tinggi masih banyak diminati konsumen, sehingga lokasi yang cukup strategis ini dimanfaatkan sebagai tambak budidaya kepiting bakau.

\section{Proses Moulting Kepiting Bakau (Scylla olivacea)}

Proses pergantian kulit atau yang disebut sebagai moulting merupakan suatu fenomena mutlak yang terjadi pada Crustaceae termasuk kepiting bakau. Namun peristiwa tersebut tidak berlangsung dalam waktu dan jumlah yang sama. Hal ini dikarenakan adanya perbedaan mekanisme fisiologis yang dipengaruhi oleh faktor internal dan eksternal masing-masing spesies. Dalam hal ini selama penelitian berlangsung untuk proses moulting kepiting bakau atau tanda- 
tanda kepiting akan melakukan moulting ketika diamati secara visual diawali dengan tubuh kepiting bakau mengalami pembengkakan atau menggembung yang kemudian keesokan harinya saat diamati kepiting telah mengalami moulting atau pergantian cangkang keras menjadi cangkang yang lebih lembut. Moulting yang terjadi pada kepiting bakau ini terjadi secara menyeluruh pada bagian tubuh kepiting.

Menurut Meyer (2007) proses moulting dimulai ketika sel-sel epidermal merespon perubahan hormon melalui laju sintesis protein. Adanya peningkatan laju sintesis protein akibat rangsangan dari hormon moulting akan menyebabkan terjadinya apolisis, yaitu pemisahan secara fisik epidermis dengan endokutikula. Berikutnya, gap akan terisi oleh sel-sel epidermal dengan larutan moulting inaktif yang kemudian menyekresi lipoprotein khusus atau lapisan kutikulin. Lapisan kutikulin ini akan menjadi bagian dari epikutikula baru. Setelah lapisan kutikulin terbentuk, lapisan moulting menjadi aktif dan zat kimianya akan mencerna endokutikula dari eksoskeleton lama. Kemudian lapisan kutikulin akan memproduksi asam amino dan mikrofibril yang selanjutnya akan didaur ulang oleh sel-sel epidermal lalu disekresi ke bawah lapisan lapisan kutikulin sebagai prokutikula yang sangat lembut dan berkerut. Kontraksi otot dan pengisisan udara akan menyebabkan tubuh kepiting menggembung ketika eksoskeleton baru telah siap, kemudian eksoskeleton lama akan retak sepanjang garis ecdysial sutures. Selanjutnya, tubuh dari eksoskeleton baru keluar dari eksoskeleton lama. Eksoskeleton baru yang masih sangat lembut dan berkerut akan terentang setelah terisi air sehingga menyebabkan ukuran kepiting bertambah setelah moulting.

\section{Durasi Moulting Kepiting Bakau (Scylla olivacea)}

Perbedaan konsentrasi bayam berpengaruh terhadap durasi moulting kepiting uji, semua perlakuan kepiting uji memiliki durasi moulting yang lebih singkat dibandingkan dengan kepiting kontrol. Dalam penelitian yang telah dilakukan terlihat bahwa kepiting uji yang diberi tambahan bayam memiliki durasi moulting yang sangat cepat (gambar 7). 


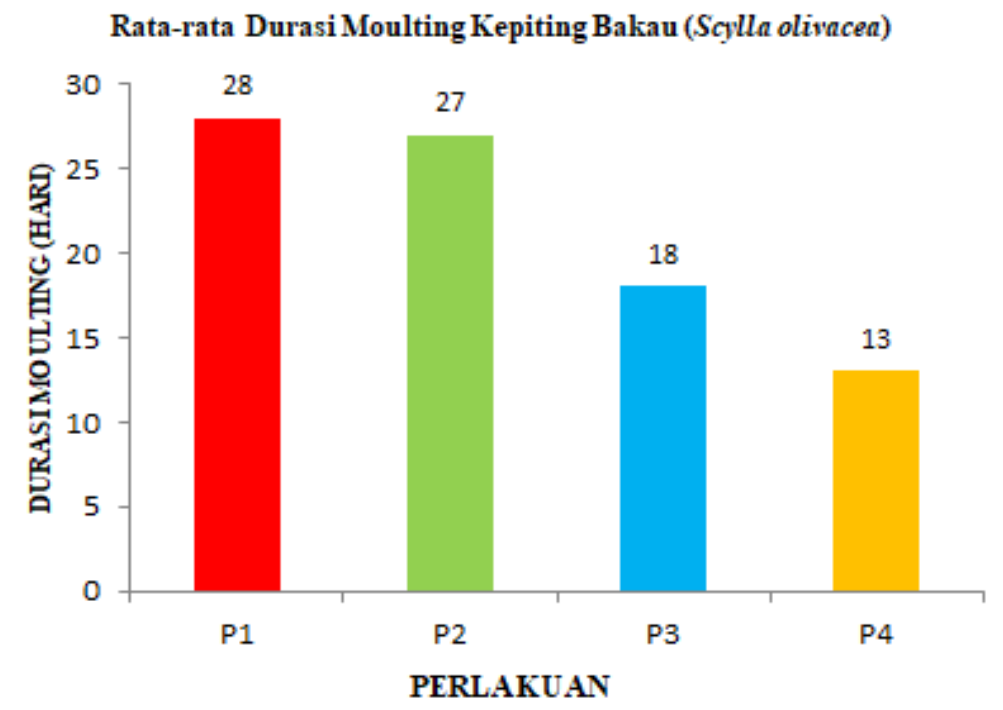

Gambar 7. Grafik Rata-rata Durasi Moulting Kepiting Bakau (Scylla olivacea)

Sesuai dengan hasil penelitian bahwa perlakuan dengan penambahan bayam 60 gr merupakan durasi moulting tercepat yaitu 13 hari (Gambar 7). Pada perlakuan yang lain kepiting uji memiliki durasi moulting yaitu 18 hari, Perlakuan dengan 20 gr bayam memiliki durasi moulting terlama yaitu 27 hari. Hasil ini jauh lebih cepat dibandingkan dengan penelitian yang dilakukan oleh Prasetyo, $d k k$ (2013), dimana penambahan 40 gr bayam memberikan durasi moulting tersingkat yaitu 36 hari, sedangkan terlama dengan penambahan 10 gr bayam yaitu 64 hari. Peningkatan konsentrasi bayam berbanding lurus dengan kecepatan moulting kepiting. Namun dalam penelitian ini belum didapatkan dosis optimal, karena pada setiap penambahan konsentrasi bayam yang diberikan respon moulting masih terus meningkat (gambar 7). Lamanya durasi moulting pada beberapa perlakuan diduga karena rendahnya konsentrasi bayam sehingga kurang optimal memacu moulting. Sedangkan kepiting kontrol atau kepiting tanpa penambahan hormon ekdisteroid yang berasal dari bayam mendapatkan durasi moulting yang paling lama dibandingkan dengan semua kepiting uji. Hal ini dikemukakan oleh Fujana dan Trijuno (2007), bahwa hormon moulting pada kepiting bakau jumlahnya sangat sedikit. Sehingga tanpa adanya penambahan hormon ekdisteroid maka proses menuju moulting akan sangat lama. Dengan penambahan hormon ekdisteroid yang berasal dari daun bayam jauh lebih aman dibandingkan dengan metode mutilasi. Hasil penelitian ini sesuai dengan yang dikemukakan oleh Feldman 
(2009) yang menjadi salah satu kelebihan dari pemberian bayam dengan hormon ekdisteroid sebagai stimulan moulting pada kepiting tidak menyebabkan kematian yang besar.

Hasil pengamatan selama penelitian menunjukkan bahwa kecepatan moulting kepiting bakau bervariasi. Secara keseluruhan durasi moulting tersingkat terdapat pada P3 yaitu pada hari ke 10 dan 15, sedangkan P2 mengalami moulting pada hari ke 17 dan 19. Selanjutnya, durasi moulting P1 terjadi pada hari ke 22 dan 31. Hal ini hampir mendekati durasi moulting kepiting kontrol yaitu pada hari 24 dan 32. Kepiting mengalami moulting pada rentang waktu 10-32 hari. Namun jika dilihat dari data, durasi moulting pada kepiting bakau (Scylla olivacea) dengan penambahan bayam sebanyak 20 gr pada pakan hampir sama dengan data kepiting kontrol dan terjadi penurunan durasi moulting. Dimana, kepiting kontrol sedikit lebih cepat melakukan moulting. Penambahan bayam pada pakan akan menambah akumulasi ekdisteroid secara eksogen. Sesuai dengan hasil yang didapatkan, P3 memacu moulting paling cepat.

Selain kandungan ekdisteroid, pada bayam juga terdapat kandungan kalsium dalam jumlah $90 \mathrm{mg} / 100$ gr bayam. Sebanyak 5\% dari kandungan yang berada pada bayam mampu diserap oleh tubuh, sisanya dalam keadaan terikat dengan asam oksalat membentuk endapan kalsium oksalat (Situmorang, 2012). Diduga, kandungan kalsium bebas yang terdapat pada bayam berbentuk $\mathrm{Ca}^{2+}$ yang turut berperan dalam memacu moutling pada kepiting uji. Dosis ekdisteroid yang tepat secara optimal akan dapat merangsang moulting kepiting uji, sedangkan dosis yang terlalu rendah akan lambat merespon moulting kepiting uji.

Konsentrasi pemberian pakan yang berbeda akan memberikan tingkat persentase moulting kepiting uji yang berbeda. Pada kelompok perlakuan dengan penambahan bayam memiliki durasi moulting yang lebih singkat dibandingkan dengan kepiting kontrol. Hasil pengamatan di lapangan menunjukkan bahwa P3 dengan penambahan 60 gr bayam pada pakan memiliki durasi moulting rata-rata paling singkat yaitu 13 hari. Selanjutnya durasi moulting P2 dengan penambahan bayam sebanyak 40 gr pada pakan rata-rata 18 hari. P1 dengan penambahan bayam 20 gr pada pakan memiliki durasi moulting sedikit lebih lama yaitu rata-rata 27 hari, hasil ini mendekati durasi moulting kepiting kontrol (P0) yaitu 28 hari. Bayam diketahui dapat mempersingkat durasi moutling kepiting bakau karena mengandung ekdisteroid. Ekdisteroid merupakan hormon yang berperan dalam mengontrol durasi moulting pada Crustaceae (Bakrim $d k k .$, 2008). 


\section{Analisa Sidik Ragam}

Berdasarkan hasil uji One Way Anova dimana $\mathrm{F}_{\text {hitung }}=4,91>4,07=\mathrm{F}_{\text {tabel }}$ yang berarti lebih besar dari nilai $\mathrm{F}_{\text {tabel}}$, yang berarti bahwa tolak $\mathrm{H}_{0}$ dan terima $\mathrm{H}_{1}$, ada pengaruh konsentrasi bayam terhadap durasi moulting kepiting bakau, berarti hasil dari uji ANOVA berbeda nyata karena memberikan pengaruh yang signifikan terhadap durasi moulting kepiting bakau dengan pengaruh konsentrasi bayam yang berbeda pada pakan. Adanya perbedaan nyata pada penelitian ini maka dilakukan uji lanjut dengan menggunakan uji Beda Nyata Terkecil (BNT) untuk mengetahui perlakuan yang terbaik.

\section{Uji Beda Nyata Terkecil (BNT)}

Berdasarkan hasil uji Beda Nyata Terkecil (BNT) terlihat bahwa rata-rata durasi moulting kepiting bakau (Scylla olivacea) tertinggi pada P3 dengan penambahan bayam 60 gram. Hasil uji BNT menyatakan bahwa P3 dengan penambahan bayam 60 gram bayam pada pakan berbeda nyata terhadap P1 dan P0 dengan penambahan bayam 20 dan 0 gram bayam atau tanpa penambahan bayam pada pakan, yang artinya ada pengaruh konsentrasi bayam terhadap durasi moulting kepiting bakau (Scylla olivacea).

\section{Kualitas Air}

Pengukuran parameter kualitas air merupakan gambaran kondisi perairan pada lokasi penelitian dimana pengukuran ini dilakukan secara langsung di tambak lokasi penelitian. Pengukuran terhadap fisika kimia perairan mencakup suhu yang diukur dengan menggunakan thermometer, salinitas diukur menggunakan refraktometer, derajat keasaman diukur dengan menggunakan $\mathrm{pH}$ meter dan oksigen terlarut diukur dengan menggunakan DO meter. Pengukuran kualitas air ini merupakan salah satu faktor pendukung keberhasilan budidaya kepiting bakau dalam menunjang keberhasilan moulting serta mengurangi dampak lain yang dapat mempengaruhi selama proses moulting kepiting bakau.

Hasil pengukuran parameter kualitas air yang didapatkan selama penelitian tersaji pada Tabel 6. 
Tabel 6. Nilai Parameter Kualitas Air Selama Penelitian

\begin{tabular}{lcccccc}
\hline Parameter Kualitas Air & P1 & P2 & P3 & P4 & P5 & Optimal \\
\hline Suhu $\left({ }^{\circ} \mathrm{C}\right)$ & $30-31$ & $30-31$ & $28-29$ & $29-32$ & $30-31$ & $25-35^{\circ} \mathrm{C}$ \\
Salinitas (ppt) & $23-24$ & $22-25$ & $22-24$ & $25-26$ & $24-25$ & $5-35 \% 0$ \\
Ph & $7,1-7,2$ & $6,9-7,1$ & $6,9-7,1$ & $7,2-7,3$ & $7,1-7,2$ & $7-9$ \\
Oksigen Terlarut (mg/l) & $5,5-5,6$ & $5,7-6,2$ & $5,4-6$ & $6-6,3$ & $5,7-5,8$ & $>5 \mathrm{mg} / 1$ \\
\hline
\end{tabular}

\section{Suhu}

Suhu merupakan salah satu parameter perairan yang penting bagi pertumbuhan, kelangsungan hidup dan moulting kepiting bakau. Hasil pengukuran suhu air selama penelitian berkisar antara $28-31^{\circ} \mathrm{C}$. Kisaran suhu selama penelitian ini relatif sama dan cukup tinggi karena pengukuran dilakukan pada siang hari sekitar jam 10 dan sudah terpapar sinar matahari. Kisaran suhu yang didapatkan selama penelitian ini adalah nilai yang baik bagi pertumbuhan dan moulting kepiting bakau. Menurut Fujaya (2008) kepiting bakau dapat hidup dengan baik pada kisaran suhu berkisar antara $25-35^{\circ} \mathrm{C}$. Menurut Adha (2015) bahwa suhu air mempengaruhi pertumbuhan dan aktivitas moulting kepiting, suhu yang lebih rendah dari $20^{\circ} \mathrm{C}$ mengakibatkan pertumbuhan kepiting lebih lambat dan proses moulting menjadi lebih lama.

\section{Salinitas}

Salinitas merupakan faktor kualitas air yang secara langsung akan mempengaruhi pertumbuhan dan keberlangsungan hidup kepiting bakau. Kisaran salinitas air selama penelitian adalah 22-25 ppt. Menurut Fujaya (2008), kepiting bakau dapat hidup pada kisaran 5-35 ppt, namun selama pertumbuhan kepiting bakau lebih menyukai salinitas rendah yaitu berkisar antara 5-25 ppt. Scylla serrata lebih cocok dibudidayakan pada salinitas tinggi yaitu 15-40 ppt, sedangkan Scylla olivacea lebih cocok dibudidayakan pada salinitas rendah yaitu 5-30 ppt (Fujaya, 2012). Secara umum kondisi salinitas di wilayah tersebut tergolong baik, karena adanya masukan air laut saat pasang dan air tawar dari sungai. 


\section{Derajat Keasaman (pH)}

Derajat keasaman atau $\mathrm{pH}$ merupakan faktor lingkungan yang berpengaruh terhadap kelangsungan hidup kepiting bakau. Kisaran pH yang diperoleh selama penelitian yaitu 6,9-7,3. Menurut Fujaya (2008), kepiting bakau dapat hidup pada pH yang berkisar antara 7-9. Dari uraian ini dikatakan bahwa kondisi tersebut layak untuk budidaya kepiting bakau.

\section{Oksigen Terlarut (DO)}

Oksigen terlarut (Dissolved Oxygen) dibutuhkan oleh semua jasad hidup untuk pernapasan, proses metabolisme atau pertukaran zat yang kemudian akan menghasilkan energi untuk pertumbuhan. Selain itu oksigen juga sangat diperlukan untuk mengurangi daya racun amoniak. Kisaran DO selama penelitian yaitu berkisar antara 5,4-6,3 mg/l. Sesuai dengan pendapat Fujaya (2012) bahwa level oksigen terlarut sebaiknya dipertahankan diatas 5 mg/l untuk keberhasilan moulting kepiting bakau. Sedangkan Christensen et all (2004) mengatakan bahwa kebutuhan minimum oksigen terlarut kepiting bakau untuk dapat hidup pada lingkungan perairan yaitu 2,65-4,0 mg/l.

\section{KESIMPULAN}

Berdasarkan hasil penelitian yang telah dilakukan dapat disimpulkan bahwa terdapat pengaruh konsentrasi bayam terhadap durasi moulting kepiting bakau. Dengan uji Beda Nyata Terkecil maka diketahui bahwa P3 dengan penambahan bayam 60 gr merupakan konsentrasi yang paling baik, yaitu berpengaruh nyata terhadap durasi moulting kepiting bakau dengan ratarata moulting 13 hari dan menjadi durasi yang paling cepat dibandingkan dengan perlakuan lainnya.

Pengukuran kualitas air selama penelitian ini adalah suhu $28-31^{\circ} \mathrm{C}$, salinitas $22-25 \mathrm{ppt}$, pH 6,9-7,3 dan DO 5,4-6,3 mg/l. Parameter kualitas air selama penelitian menunjukkan bahwa kondisi perairan cukup baik dan mendukung kehidupan kepiting bakau. 


\section{DAFTAR PUSTAKA}

Adha, M. 2015. Analisis Kelimpahan Kepiting Bakau (Scylla spp.) di Kawasan nangrove Dukuh Senik, Desa Bendono, Kecamatan Sayung, Kabupaten Demak. [Skripsi]. Jurusan Pendidikan Biologi. Universitas Walisongo Semarang. $74 \mathrm{hlm}$.

Bakrim A, Maria A, Sayah A, Lafont R, \& Takvorian N. 2008. Ecdysteroids in spinach (Spinacia oleracea L.): Biosiynthesis, transport and regulation of levels. Online Abstract. Plant Physiology and Biochemistry, 46 (10): 844-854.

Christensen SM., Macintosh DM., Phuong NT. 2004. Pond Production of The Mud Crabs Scylla paramamosain (Estampador) and S. Olivacea (Herbin The Mekong Delta, Vietnam, Using Two Differensupplementary Diets. Aquaculture Research (35): 1013-1024.

Dwi Agus P, Andika. 2013. Penambahan Air Kapur dan Bayam pada Pakan untuk Mempersingkat Durasi Molting Kepiting Bakau (Scylla serrata) Jantan. LenteraBio : Berkala Ilmiah Biologi, 2(3).

Feldman, J.I.G. 2009. Phytoecdysteroids; Understanding Their Anabolic Activity. Dissertation. The State University of New Jersey. 143 hal.

Fujaya, Y. 2007. Mempersiapkan Kepiting Menjadi Komoditas Andalan. Unhas.

Fujaya Y, Suryati, Nurcahyono, Alam. 2008. Titer Ekdisteroid Hemolimph Dan Cirri Morfologi Rajungan Selama Fase Molting Dan Reproduksi. Jurnal Torani, 18(3) : 266-274.

Fujaya Y., D.D. Trijuno, dan E. Suryati. 2008. Pengembangan Teknologi Produksi Rajungan Lunak Hasil Pembenihan dengan Memanfaatkan Ekstrak Bayam Sebagai Stimulan Molting. Laporan Penelitian Tahun II, RISTEK-program insentif riset terapan, MENRESTEK. Fakultas Ilmu Kelautan dan Perikanan, Universitas Hasanuddin, Makassar.

Fujaya Y, S. Aslamyah, Mufidah, \& L.F. Mallombasang. 2009. Peningkatan Produksi dan Efisiensi Proses Produksi Kepiting Cangkang Lunak (Soft shell crab) Melalui Aplikasi Teknologi Industri Molting yang Ramah Lingkungan. Laporan Penelitian Tahun I, RAPID, DIKTI. Fakultas Ilmu Kelautan dan Perikanan, Universitas Hasanuddin, Makassar. 
Harianto, E. 2015. Kinerja Produksi Kepiting Bakau (Scylla serrata) Cangkang Lunak pada Metode Pemotongan Capit dan Kaki Jalan, Popey dan Alami. Jurnal Ilmiah Universitas Batanghari Jambi. Vol. 15(1) : 15-21.

Karim, M. Y. 2013. Kepiting Bakau (Scylla spp.) Bioekologi, Budidaya dan Pembenihannya. Penerbit Yarsif Watampone, Jakarta.

Kordi. 2004. Budidaya Kepiting di Tambak Sistem Polikultur. Semarang. Dahara Prize.

Meyer, J.R. 2007. Morphogenesis. Department of entomologi NC State University. Diunduh tanggal 27 September 2007.

Permadi, S., \& Juwana, S. 2016. Penetapan Kebutuhan Harian Pakan Ikan Rucah untuk Penggemukan Kepiting Bakau di Keramba Jaring Dasar. OLDI (Oseanologi dan Limnologi di Indonesia), 1(1)) : 75-83.

Situmorang, N.O. 2012. Perbandingan Metode Destruksi Kering dengan Destruksi Basah Terhadap Kadar Ion Kalsium pada Daun Tanaman Bayam Merah dan Daun Tanaman Bayam Hijau (Amaranthus Tricolor) Secara Spektrofotometri Serapan Atom (SSA). Universitas Sumatra Utara: Skripsi. 